Agro-Science Journal of Tropical Agriculture, Food, Environment and Extension Volume 21 Number 1 (January 2022) pp. $7-14$

ISSN 1119-7455

\title{
PLANTING DATE AND FERTILIZER TYPE INFLUENCED SOIL QUALITY INDICES AND SOYBEAN (Glycine max L.) YIELDS IN DERIVED SAVANNAH OF NIGERIA
}

\author{
Nwite J.C. \\ Department of Crop Production Technology, Federal College of Agriculture, Ishiagu, Nigeria \\ Corresponding email: johnsmallpot@gmail.com
}

\begin{abstract}
Soybean is grown in many parts of Northern Nigeria, with little climatic challenges and soil organic matter. There is need to investigate possible influence of planting date of the crop in Southeastern Nigeria, an environment that is rather foreign to the crop. A study was carried out in 2018 and 2019 cropping seasons at Federal College of Agriculture, Ishiagu, Ebonyi State, to evaluate the influence of different planting dates and fertilizer types on selected soil physical and chemical properties, growth and yield of soybean. A split plot in a randomized complete block design was used with planting date (May and June) as the main plots, while six

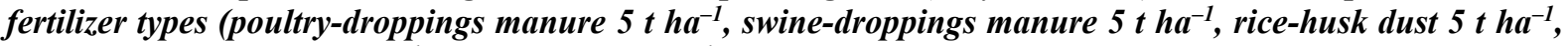
NPK 15:15:15 at $150 \mathrm{~kg} \mathrm{ha}^{-1}$, urea at $100 \mathrm{~kg} \mathrm{ha}^{-1}$ and the control) constituted the sub-plots. At crop maturity, some soil quality indices and pod and grain yields $\left(t \mathrm{ha}^{-1}\right)$ of soybean were assessed. Soil organic carbon (SOC) and total nitrogen contents were significantly $(p<0.05)$ influenced by both planting date and fertilizer type in 2018 and 2019, while soil $p H$ was improved significantly $(p<0.05)$ only by fertilizer type in these two cropping seasons. Mean-weight diameter of aggregates, soil bulk density and SOC stock as well as soybean yields were significantly $(p<0.05)$ influenced by both planting date and fertilizer type in the two seasons. Generally, planting in May improved soil total nitrogen and soybean pod yield whereas planting in June improved the other soil quality indices and soybean grain yield, the best soil amendment in either case being poultry-droppings manure but sometimes parameter-specific. The choice of planting date (May or June) in soybean production in the derived savannah and the soil amendment to use in the enterprise thus has both agronomic and environmental implications. Such a choice would depend on the indices of soil quality and/or the aspects of soybean yields (pod or grain) whose improvements the farmer intends to achieve at crop maturity.
\end{abstract}

Key words: early planting, organic amendments, soil physico-chemical properties, soybean grain yield

\section{INTRODUCTION}

Soybean (Glycine max L. Merrill) is the world's leading source of oil and protein. (Fekadu et al., 2009; Alghamdi, 2004). The spread of soybean from its native land of origins has been mainly due to its adaptability and predominant use as a food crop for human nutrition, source of protein for animals (Yusuf and Idowu, 2001). Traditionally, soybean is widely grown in the middle belt or the savannah zone of Nigeria (Okpara and Ibiam, 2000), but its production had presently expanded beyond the traditional production areas otherwise considered unsuitable or marginal for soybean production (Asiegbu and Okpara, 2002; Obalum et al., 2011a).

However, the planting time of soybean in these new areas varies due to differences in weather and soil type. Planting date is a critical factor affecting soybean growth, grain yield (Zhang et al., 2010), and grain quality (Rahman et al., 2005). Sowing date is the variable with the largest effect on crop yield (Calvino et al., 2003). Effects of planting date on soybean yield and other traits vary according to locations (Naeve et al., 2004). Environmental conditions associated with late sowing affect crop features related to the capture of radiation and other portions of crop resources such as vegetative growth at all phenological stages of the crop including the reproductive phases (Kantolic and Slafer, 2001).

Early planting of legume crops aids in early plant cover which provide good coverage and organic matter. The cover decreases the bulk density of the soil due to organic matter effect (Calegari, 2006). Early planting thus improves the physical, chemical and biological conditions of the soil while also contributing to weed control and water conservation. Research has shown that cropping systems in relation to time of planting usually influence the level of soil carbon stock in the tropics (Lal, 2003). Determination of appropriate period of planting different crops is a strategy of improving carbon sequestration and reducing carbon accumulation in the atmosphere (Jarecki and Lal, 2003).

Please cite as: Nwite J.C. (2022). Planting date and fertilizer type influenced soil quality indices and soybean (Glycine max L.) yields in derived savannah of Nigeria. Agro-Science, 21 (1), 7-14. DOI: https://dx.doi.org/10.4314/as.v21i1.2 
For centuries, organic materials have been applied as manures to agricultural soils as a means of enhancing the status of soil organic carbon (SOC) with numerous benefits to soil structure, soil fertility (Balashor et al., 2010), and overall soil quality (Obalum et al., 2017). Manures are, therefore, fundamental for carbon recycling and sequestration in the soil which often promote soil aggregation, water retentivity and plant nutrients availability (Ohu et al., 2009). Indeed, use of manures in soil fertility management, by virtue of affecting SOC, may have a far-reaching impact because of the critical role of the soil in the global carbon cycle (Bronick and Lal, 2005; Eshel et al., 2007; Adesodun and Odejimi, 2010).

However, the well-known pressure on agricultural soils and declining soil fertility has necessitated the use of both manures and mineral fertilizers in crop production (Nottidge et al., 2005; Nwite et al., 2012a,b; Nwite et al., 2013; Unagwu et al., 2013; Nwite et al., 2016a; Nnadi et al., 2021). Sole use of fertilizers is cost-prohibitive and not sustainable due to ensuing soil-related problems such as soil acidity, nutrient imbalance and deterioration of soil structure (Nottidge et al., 2005). These undesirable effects in the soil rarely occur and not as evident with manures (Nwite et al., 2016b). With respect to soil properties and crop yields, complementary use of manures and mineral fertilizers has been widely advocated.

Within the context of the integrated soil fertility management, co-application of poultry manure and NPK fertilizer for tuberizing cover crops has shown to be promising with regard to soil properties and crop yields in the derived savannah of southeastern Nigeria (Nnadi et al., 2020; Obalum et al., 2020). For the dominant coarse-textured soils in this zone, indications are that the one to improve soil fertility indices over the other between poultry manure and NPK fertilizer under leguminous cover crops in index-specific; the former for soil $\mathrm{pH}$, total nitrogen (N) and available phosphorus (P), but the latter for exchangeable potassium (K) and other relevant soil cation exchange indices (Umeugokwe et al., 2021). For a better understanding, the effects of these and other soil amendments on soil fertility need to be co-studied with confounding environmental factors and evaluated too using leguminous cover crops.

In their study of tillage-mulch management practices in the zone, Obalum et al. (2011a) found that soybean was not affected by managementinduced changes in soil structure. They reported, however, that the tillage-mulch practices influenced root-zone moisture storage (Obalum et al., 2012a), and selected indices of soil quality and fertility (Obalum et al., 2011b), though not necessarily in a congruent pattern. This suggests that relative wetness of the soil environment as expected to progressively increase from the onset of rains till the time of planting could influence nutrients release in the soil, such that planting date could be a critical factor in soybean production. The insensitivity of soybean to soil structure may extend to changes in soil structure due to use of manures and mineral fertilizers, if such changes are not obliterated by the surface coverage offered by the crop. This study, therefore, aimed at evaluating the effects of different planting dates of soybean and fertilizer types on selected soil physical and chemical properties (including carbon stock) and yield responses of soybean in the derived savannah.

\section{MATERIALS AND METHODS Description of Experimental Site}

The experiment was carried out at the Research and Teaching Farm of Federal College of Agriculture, Ishiagu, Ebonyi State, Nigeria, during 2018 and 2019 cropping seasons, located by $05^{\circ} 56^{\prime} \mathrm{N}$ and $07^{\circ} 41^{\prime} \mathrm{E}$. Mean annual rainfall and mean monthly temperature are $1350 \mathrm{~mm}$ and $30^{\circ} \mathrm{C}$, respectively. The area lies within the derived savannah zone of southeastern Nigeria. There are two distinct seasons, dry season (Nov. to Mar.) and rainy season (Apr. to Oct.).

The meteorological data of the study area showed that in 2018, the highest rainfall amount $(304.8 \mathrm{~mm})$ was recorded in the month of October with a temperature of $32{ }^{\circ} \mathrm{C}$ while in 2019 the highest amount of rainfall $(420 \mathrm{~mm})$ in the area was obtained in the month of August (Table 1). No rainfall was recorded in the months of February and January in 2018 and 2019, respectively in the area. Generally, low rainfall was recorded in the early part of the two years of study.

Geologically the area is underlain by sedimentary rock derived from successive deposit of the cretaceous and tertiary period and lies within Asu River group (Lekwa et al., 1995). This geological formation consists of olive brown sandy shale, fine grained micaeous sandstones and mudstones deposited in an alternating sequence.

Table 1: Some meteorological data for 2018 and 2019 cropping seasons of the study area

\begin{tabular}{lcccccc}
\hline & \multicolumn{3}{c}{ \% Rel. } & \multicolumn{2}{c}{$\begin{array}{c}\text { Rainfall } \\
(\mathrm{mm})\end{array}$} & \multicolumn{2}{c}{$\begin{array}{c}\text { Temp. } \\
\left({ }^{\circ} \mathrm{C}\right)\end{array}$} \\
& 2018 & 2019 & 2018 & 2019 & 2018 & 2019 \\
\hline Jan. & 58.0 & 62.0 & 2.5 & 0.0 & 35.0 & 32.0 \\
Feb. & 77.0 & 83.0 & 0.0 & 36.4 & 35.0 & 33.0 \\
Mar. & 80.0 & 86.0 & 17.7 & 62.8 & 37.0 & 34.0 \\
Apr. & 68.0 & 88.0 & 8.6 & 181.6 & 37.0 & 31.0 \\
May & 76.0 & 90.0 & 158.7 & 341.3 & 35.0 & 31.0 \\
Jun. & 86.0 & 89.0 & 158.7 & 262.1 & 30.0 & 32.0 \\
Jul. & 89.0 & 94.0 & 214.8 & 300.4 & 31.0 & 30.0 \\
Aug. & 90.0 & 92.0 & 283.7 & 420.0 & 29.0 & 32.0 \\
Sep. & 53.0 & 90.0 & 212.2 & 342.7 & 31.0 & 32.0 \\
Oct. & 53.0 & 78.0 & 304.8 & 114.9 & 32.0 & 30.0 \\
Nov. & 86.0 & 88.0 & 122.3 & 80.0 & 34.0 & 32.0 \\
Dec. & 75.0 & - & 2.3 & & 36.0 & - \\
Total & & & 1486.3 & 2142.2 & & \\
\hline
\end{tabular}




\section{Experimental Design and Field Layout}

A split plot in randomized complete block design was used to assess two factors at different levels. Two planting dates (May and June) were the main plots, while the five different fertilizer types and the control constituted the sub-plots replicated three times. The sub-plots were swine-droppings manure at $5 \mathrm{tha}^{-1}$, poultry-droppings manure at 5 $\mathrm{t} \mathrm{ha} \mathrm{a}^{-1}$, rice-husk dust at $5 \mathrm{t} \mathrm{ha}^{-1}$, NPK-15:15:15 at $150 \mathrm{~kg} \mathrm{ha}^{-1}$, Urea (NPK 46:0:0) at $100 \mathrm{~kg} \mathrm{ha}^{-1}$ and control. Because the N-fixing ability of soybean positively relates with soil P (Ogoke et al., 2006), rice-husk ash at $5 \mathrm{t} \mathrm{ha}^{-1}$ was uniformly added to boost the soil's P status and as basal organic lime (Nwite et al., 2011, 2012c). The nutrient contents of the organic amendments are shown in Table 2.

The land for the study was cleared and the trashes removed from the site. It was ploughed, harrowed and later manually made into $1.5 \mathrm{~m} \times 1.5 \mathrm{~m}$ beds which were the sub-plots. The organic amendments were applied uniformly and incorporated into the soil. A period of one week was allowed for their decomposition before planting. The NPK and urea were applied two weeks after planting (WAP). Rice-husk ash was applied basally two days before planting. The soybean seeds were sown at two seeds per hole at a spacing of $30 \mathrm{~cm} \times 30 \mathrm{~cm}$ on 10th May and 10th June in both years of the study. Weeding was done manually at 4 and 8 WAP.

\section{Data Collection}

\section{Collection of plant parameters}

Yield attributes measured were weight of pods and grain yield at harvest. Weight of pods was obtained as the weight of all the soybean pods harvested from a given treatment plot and extrapolated to its equivalent in $\mathrm{t} \mathrm{ha}^{-1}$. After threshing these pods, the seeds got were weighed to obtain their weight regarded as grain yield, which too was extrapolated to its equivalent in $\mathrm{t} \mathrm{ha}^{-1}$. For both parameters, weights were measured using a weighing balance.

\section{Soil sampling and laboratory techniques}

At the commencement of the study, soil sampling was done from random points at the site. The soil samples were collected from the $0-20 \mathrm{~cm}$ depth using a soil auger; these were merged into a composite sample. At the end of soybean harvest, another set of auger samples was collected from the top- $(0-20 \mathrm{~cm})$ soil depth of strategic sampling points in each plot and composited for laboratory analysis. Soil cores were also collected from about the plots for the determination of soil bulk density.

Table 2: Nutrient compositions $\left(\mathrm{g} \mathrm{kg}^{-1}\right)$ of some of the organic soil amendments

\begin{tabular}{llcl}
\hline Property & Poultry droppings & Rice-husk dust & Rice-husk ash \\
\hline Organic carbon & 165.2 & 337.5 & 38.9 \\
Nitrogen & 21.0 & 7.0 & 0.6 \\
Phosphorus & 25.5 & 4.9 & 119.4 \\
Potassium & 4.8 & 1.2 & 17.7 \\
Calcium & 144.0 & 3.6 & 16.0 \\
Magnesium & 12.0 & 3.9 & 15.0 \\
Sodium & 3.4 & 2.2 & 3.3 \\
\hline
\end{tabular}

Soil fractions less than $2 \mathrm{~mm}$ from individual samples were then analyzed for soil $\mathrm{pH}$ in a 1:2.5 soil and 0.1 M KCl suspensions (McLean, 1982), SOC by the Walkley-Black method as described by Nelson and Sommers (1982), and total nitrogen (N) by semi-micro Kjeldahl digestion method using sulphuric acid and $\mathrm{CuSO}_{4}$ and $\mathrm{Na}_{2} \mathrm{SO}_{4}$ catalyst mixture (Bremner and Mulvaney, 1982).

Mean-weight diameter (MWD) of aggregates (Kemper and Rosenau, 1986) was calculated as:

$$
M W D_{w}=\sum_{i=1}^{n}\left(X_{i} W_{i}\right) ;
$$

where $X_{i}$ is the mean diameter of the $i^{\text {th }}$ sieve size and $W_{i}$ is the proportion of the total aggregates in the $i^{\text {th }}$ fraction. The higher the MWD values, the higher proportion of macro-aggregates in the sample and thus better stability. Core samples were allowed to drain freely for $24 \mathrm{~h}$ before determination of soil bulk density by Blake and Hartge's (1986) method. Carbon stock in $\mathrm{kg} \mathrm{m}^{-2}$ was estimated as $\%$ carbon $/ 100 \times$ soil bulk density $\times$ area of hectare $\left(10,000 \mathrm{~m}^{2}\right) \times$ soil depth $(\mathrm{m})$ (Obalum et al., 2012b).

\section{Data Analysis}

Data analysis was performed using GenStat 37.2 edition. Treatment means were separated and compared using Least Significant Difference and all inferences were made at $5 \%$ level of probability.

\section{RESULTS AND DISCUSSION Selected Physical and Chemical Properties of the Soil (0-20 cm) Soil Depth}

The physical and chemical properties of the soil before application of amendments are shown in Table 3. The soil is a sandy-loam with total sand, silt and clay contents as $71 \%, 19 \%$ and $10 \%$, respectively. Some of the chemical components of the soil showed that $\mathrm{N}, \mathrm{P}, \mathrm{K}, \mathrm{Ca}, \mathrm{Mg}$ and $\mathrm{Na}$ contents including SOC concentration were low at the beginning of the study. These low values are expected to be improved through the application of manure (Nwite et al., 2008; Nwite et al., 2019). The $\mathrm{pH}$ was slightly acidic with a value of 5.8.

Table 3: Initial physical and chemical characteristics of the studied soil before planting

\begin{tabular}{lc}
\hline Soil properties & Values \\
\hline Particle size distribution $\left(\mathrm{g} \mathrm{kg}^{-1}\right)$ & \\
Clay & 100 \\
Silt & 190 \\
Fine sand & 530 \\
Coarse sand & 180 \\
Texture class & Sandy loam \\
Organic carbon $\left(\mathrm{g} \mathrm{kg}^{-1}\right)$ & 7.19 \\
Total nitrogen $\left(\mathrm{g} \mathrm{kg}^{-1}\right)$ & 1.12 \\
pH $\left(\mathrm{H}_{2} \mathrm{O}\right)$ & 5.80 \\
Exchangeable bases $\left(\mathrm{me} 100 \mathrm{~g}^{-1}\right)$ & \\
Sodium $\left(\mathrm{Na}^{+}\right)$ & 0.04 \\
Calcium $\left(\mathrm{Ca}^{2+}\right)$ & 1.60 \\
Potassium $\left(\mathrm{K}^{+}\right)$ & 0.07 \\
Magnesium $\left(\mathrm{mg}^{2+}\right)$ & 1.20 \\
Cation exchange capacity $\left(\mathrm{cmol} \mathrm{kg}^{-1}\right)$ & 13.20 \\
Exchangeable acidity $\left(\mathrm{cmol} \mathrm{kg}^{-1}\right)$ & 1.20 \\
Available phosphorous $\left(\mathrm{mg} \mathrm{kg}^{-1}\right)$ & 7.46 \\
\hline
\end{tabular}


Influence of Planting Date and Fertilizer Type on Soil pH, Total Nitrogen and Organic Carbon Soil $\mathrm{pH}$ did not significantly $(p>0.05)$ vary due to planting dates in 2018 and 2019 (Table 4). Soil amendments had significant $(p<0.05)$ effects on soil $\mathrm{pH}$. Thus, the soil amendments positively influenced soil $\mathrm{pH}$, with highest and lowest values in poultry droppings-amended and the control plots, respectively in both cropping seasons. This could be attributed to the required level of temperature and moisture as well as the nutrient elements for the enhancement of the soil $\mathrm{pH}$. This is in conformity with the work of Mbah et al. (2017) who reported $\mathrm{pH}$ increase following the application of organic manure. However, interaction of rice husk dust $\times$ plants sown in June significantly $(p<$ $0.05)$ gave the highest $\mathrm{pH}$ value (6.83) in 2019.

Soil organic carbon (SOC) was significantly $(p<0.05)$ higher in June than May in both years of the study (Table 4). Soil amendments also significantly increased the SOC pool in those two years. Poultry droppings increased SOC, similar to urea and rice-husk dust in 2018 and 2019, respectively. This is in conformity with the Bronick and Lal (2005) who reported a direct relationship between organic matter application and the final SOC.
Total nitrogen $(\mathrm{N})$ content varied significantly $(p<0.05)$ with planting time and soil amendments in the two years of the study. It was higher in May than June in both years. This could be attributed to low temperature and soil moisture content in May when the planting was made, which reduced the evaporation and leaching of $\mathrm{N}$ in the soil. Rainfall and temperature effects on soil $\mathrm{N}$ content has been reported (Wan et al., 2001). Nitrogen is easily lost by volatilization from a system during an intense temperature (Fatubarin and Olojugba, 2014). The results (Table 4$)$ indicated significant $(p<0.05)$ improvement in total $\mathrm{N}$ with poultry-droppings and swine-droppings manures giving higher values ( 1.08 and $1.00 \mathrm{~g} \mathrm{~kg}^{-1}$, respectively) in 2019. This could be attributed to the gradual decomposition of manure and its slow release of $\mathrm{N}$ (Liu et al., 2010).

The interaction planting dates $\times$ fertilizer types significantly $(p<0.05)$ influenced SOC in both years of the study, whereby the highest values were due to poultry droppings or rice-husk dust applied in June. The effect of rice-husk dust here is linked to its high carbon (Adubasim et al., 2018) However, the interaction showed that rice-husk dust applied in May enhanced total $\mathrm{N}$ more than the other treatments in 2018, with a tendency for similar effect in 2019.

Table 4: Effects of different planting dates and fertilizer types on soil $\mathrm{pH}$, total nitrogen, and soil organic carbon

\begin{tabular}{|c|c|c|c|c|c|c|}
\hline \multirow{2}{*}{ Amendments } & \multicolumn{3}{|c|}{2018} & \multicolumn{3}{|c|}{2019} \\
\hline & May & June & Mean & May & June & Mean \\
\hline & \multicolumn{6}{|c|}{ Soil $\mathrm{pH}-\mathrm{H}_{2} \mathrm{O}$} \\
\hline Control & 5.33 & 5.40 & 5.37 & 5.23 & 5.43 & 5.33 \\
\hline NPK-15:15:15 & 5.77 & 5.70 & 5.73 & 5.63 & 5.53 & 5.58 \\
\hline Poultry-droppings manure & 6.00 & 6.27 & 6.13 & 6.60 & 6.77 & 6.68 \\
\hline Rice-husk dust & 5.73 & 5.83 & 5.78 & 6.13 & 6.83 & 6.48 \\
\hline Swine-droppings manure & 5.80 & 5.77 & 5.78 & 6.10 & 6.10 & 6.10 \\
\hline Urea N-fertilizer & 5.47 & 5.50 & 5.48 & 5.40 & 5.47 & 5.43 \\
\hline Mean & 5.68 & 5.74 & 5.71 & 5.85 & 6.02 & 5.94 \\
\hline $\mathrm{LSD}_{0.05}$ for planting dates & & NS & & & NS & \\
\hline $\mathrm{LSD}_{0.05}$ for amendments & & 0.15 & & & 0.21 & \\
\hline \multicolumn{2}{|c|}{$\mathrm{LSD}_{0.05}$ for planting dates $\times$ amendments } & NS & & & 0.30 & \\
\hline & \multicolumn{6}{|c|}{ Soil organic carbon $\left(\mathrm{g} \mathrm{kg}^{-1}\right)$} \\
\hline Control & 0.329 & 0.881 & 0.605 & 0.427 & 0.782 & 0.604 \\
\hline NPK-15:15:15 & 0.522 & 1.095 & 0.809 & 0.867 & 1.088 & 0.978 \\
\hline Poultry-droppings manure & 0.980 & 1.157 & 1.069 & 1.152 & 1.182 & 1.167 \\
\hline Rice-husk dust & 0.779 & 1.129 & 0.954 & 1.079 & 1.217 & 1.148 \\
\hline Swine-droppings manure & 0.886 & 1.015 & 0.950 & 0.917 & 1.071 & 0.994 \\
\hline Urea $\mathrm{N}$-fertilizer & 1.050 & 1.047 & 1.049 & 1.094 & 1.078 & 1.086 \\
\hline Mean & 0.758 & 1.054 & 0.906 & 0.923 & 1.070 & 0.996 \\
\hline $\mathrm{LSD}_{0.05}$ for planting dates & & 0.150 & & & 0.050 & \\
\hline $\mathrm{LSD}_{0.05}$ for amendments & & 0.102 & & & 0.094 & \\
\hline \multicolumn{2}{|c|}{$\mathrm{LSD}_{0.05}$ for planting dates $\times$ amendments } & 0.152 & & & 0.124 & \\
\hline & \multicolumn{6}{|c|}{ Total nitrogen $\left(\mathrm{g} \mathrm{kg}^{-1}\right)$} \\
\hline Control & 0.70 & 0.74 & 0.72 & 0.86 & 0.75 & 0.80 \\
\hline NPK-15:15:15 & 1.27 & 0.61 & 0.94 & 1.01 & 0.71 & 0.86 \\
\hline Poultry-droppings manure & 1.16 & 0.75 & 0.96 & 1.17 & 1.00 & 1.08 \\
\hline Rice-husk dust & 1.03 & 0.65 & 0.84 & 1.05 & 0.81 & 0.93 \\
\hline Swine-droppings manure & 1.03 & 0.65 & 0.84 & 1.03 & 0.95 & 1.00 \\
\hline Urea $\mathrm{N}$-fertilizer & 0.45 & 0.65 & 0.55 & 0.84 & 0.73 & 0.79 \\
\hline Mean & 0.94 & 0.67 & 0.806 & 1.00 & 0.82 & 0.91 \\
\hline $\mathrm{LSD}_{0.05}$ for planting dates & & 0.16 & & & 0.01 & \\
\hline $\mathrm{LSD}_{0.05}$ for amendments & & 0.13 & & & 0.12 & \\
\hline $\mathrm{LSD}_{0.05}$ for planting dates $\times$ & ments & 0.18 & & & NS & \\
\hline
\end{tabular}


Influence of Planting Date and Fertilizer type on Mean-Weight Diameter of Soil Aggregates, Soil Bulk Density and Soil Organic Carbon Stock The MWD was significantly $(p<0.05)$ higher in June than in May (Table 5). This could be attributed to the increased rainfall and temperature which leads to quick decomposition of the organic amendments and improvement on the soil aggregates. The higher MWD recorded in June in both 2018 and 2019 (0.6839 and $0.6379 \mathrm{~mm}$, respectively) indicated increased macro-aggregates in the soil which can be attributed to increased leaching below $20 \mathrm{~cm}$ soil depth of most silt and clay materials on the topsoil. This situation depicts an increased natural drainage in the soil during the study. This could be good attributes for arable crops grown in the studied area as the soil will always be drained. Soil amendments caused significant $(p<0.05)$ variations in the MWD with the highest values in the NPK amended soil in the two years of study.

Soil bulk density was significantly $(p<0.05)$ higher $\left(1.71\right.$ and $\left.1.68 \mathrm{Mg} \mathrm{m}^{-3}\right)$ in plots planted in the month of May in 2018 and 2019 seasons, respectively. This implies that plots cultivated in June reduced bulk density drastically than those cultivated in May, which could be attributed to variation in the environmental factor. The decrease in soil bulk density in June could be related to the increased aggregation as a result of higher level of MWD, hence increase in rooting depth of plants.
The results show that swine-droppings manure significantly $(p<0.05)$ reduced soil bulk density $\left(1.58 \mathrm{Mg} \mathrm{m}^{-3}\right.$ ) better in 2018, while rice-husk dust significantly $(p<0.05)$ decreased it $\left(1.51 \mathrm{Mg} \mathrm{m}^{-3}\right)$ in 2019 (Table 5). In these two years, control plots increased the soil bulk density compared to the amended plots. This indicates that application of manure to cultivated soils increases SOC level in them. Specifically, management-induced increases in the organic carbon level of sandy-loam soils often reflect as a reduction in their bulk density and hence an increase in their aggregate stability (Bhattacharyya et al., 2007; Obalum and Obi, 2014).

Table 5 shows that soil carbon stock varied significantly $(p<0.05)$ between soils cultivated in May and June in both 2018 and 2019. Cultivation in June significantly $(p<0.05)$ improved the carbon stock higher than cultivation in May. This could be as a result of increased moisture content of the soil that had received fertilizers leading to increased SOC pool (Wang et al., 2010). The results also showed variations in carbon stock due to amendments. In 2018 being the first year of the study, plots amended with urea fertilizer recorded the highest carbon stock followed by poultry droppings treated plots. In 2019, poultry droppings treated plots significantly $(p<0.05)$ improved the soil carbon stock more, followed by rice-husk dust and urea fertilizer amended plots.

Table 5: Effects of planting date and fertilizer type on soil aggregation and organic carbon stock

\begin{tabular}{|c|c|c|c|c|c|c|}
\hline \multirow{2}{*}{ Amendments } & \multicolumn{3}{|c|}{2018} & \multicolumn{3}{|c|}{2019} \\
\hline & May & June & Mean & May & June & Mean \\
\hline & \multicolumn{6}{|c|}{ Mean-weight diameter (MWD) of soil aggregates (mm) } \\
\hline Control & 0.6286 & 0.6529 & 0.6407 & 0.6424 & 0.5967 & 0.6195 \\
\hline NPK-15:15:15 & 0.5397 & 1.1405 & 0.8401 & 0.5914 & 0.7859 & 0.6887 \\
\hline Poultry-droppings manure & 0.5691 & 0.6810 & 0.6250 & 0.5613 & 0.6686 & 0.6149 \\
\hline Rice-husk dust & 0.4766 & 0.4739 & 0.4752 & 0.6169 & 0.5764 & 0.5967 \\
\hline Swine-droppings manure & 0.5750 & 0.5605 & 0.5678 & 0.5675 & 0.5961 & 0.5818 \\
\hline Urea N-fertilizer & 0.5186 & 0.5944 & 0.5565 & 0.5745 & 0.6038 & 0.5892 \\
\hline Mean & 0.5513 & 0.6839 & 0.6176 & 0.5923 & 0.6379 & 0.6151 \\
\hline $\mathrm{LSD}_{0.05}$ for planting dates & & 0.0185 & & & 0.0386 & \\
\hline $\mathrm{LSD}_{0.05}$ for amendments & & 0.0365 & & & 0.0599 & \\
\hline \multirow[t]{2}{*}{$\mathrm{LSD}_{0.05}$ for planting dates $\times$ amendments } & & 0.0478 & & & 0.0791 & \\
\hline & \multicolumn{6}{|c|}{ Soil bulk density $\left(\mathrm{g} \mathrm{cm}^{-3}\right)$} \\
\hline Control & 1.82 & 1.75 & 1.79 & 1.70 & 1.62 & 1.66 \\
\hline NPK-15:15:15 & 1.76 & 1.68 & 1.72 & 1.70 & 1.56 & 1.63 \\
\hline Poultry-droppings manure & 1.67 & 1.59 & 1.63 & 1.67 & 1.43 & 1.55 \\
\hline Rice-husk dust & 1.63 & 1.56 & 1.60 & 1.50 & 1.51 & 1.51 \\
\hline Swine-droppings manure & 1.66 & 1.50 & 1.58 & 1.58 & 1.48 & 1.53 \\
\hline Urea N-fertilizer & 1.75 & 1.62 & 1.69 & 1.65 & 1.55 & 1.60 \\
\hline Mean & 1.72 & 1.62 & 1.67 & 1.64 & 1.52 & 1.58 \\
\hline $\mathrm{LSD}_{0.05}$ for planting dates & & 0.08 & & & 0.07 & \\
\hline $\mathrm{LSD}_{0.05}$ for amendments & & 0.09 & & & 0.11 & \\
\hline \multirow[t]{2}{*}{$\mathrm{LSD}_{0.05}$ for planting dates $\times$ amendments } & & NS & & & NS & \\
\hline & \multicolumn{6}{|c|}{ Soil organic carbon stock $\left(\mathrm{kg} \mathrm{m}^{-2}\right)$} \\
\hline Control & 11.98 & 31.00 & 21.49 & 14.59 & 25.35 & 19.97 \\
\hline NPK-15:15:15 & 18.34 & 36.75 & 27.54 & 29.48 & 33.81 & 31.64 \\
\hline Poultry-droppings manure & 32.59 & 36.97 & 34.78 & 38.55 & 34.05 & 36.30 \\
\hline Rice-husk dust & 25.36 & 35.23 & 30.29 & 32.47 & 36.70 & 34.58 \\
\hline Swine-droppings manure & 29.48 & 30.48 & 29.98 & 28.93 & 31.78 & 30.36 \\
\hline Urea N-fertilizer & 36.75 & 33.92 & 35.34 & 36.18 & 33.40 & 34.79 \\
\hline Mean & 25.75 & 34.06 & 29.90 & 30.03 & 32.51 & 31.27 \\
\hline $\mathrm{LSD}_{0.05}$ for planting dates & & 3.93 & & & 0.46 & \\
\hline $\mathrm{LSD}_{0.05}$ for amendments & & 4.32 & & & 4.15 & \\
\hline $\mathrm{LSD}_{0.05}$ for planting dates $\times$ amendments & & 5.85 & & & 5.36 & \\
\hline
\end{tabular}

LSD, least significant difference; NS, non-significant 


\section{Influence of Planting Date and Fertilizer Type on Pod and Grain Yields of Soybean}

Planting date significantly $(p<0.05)$ influenced soybean pod weight in this study (Table 6). Plots cultivated in May had higher weight $\left(7.21 \mathrm{t} \mathrm{ha}^{-1}\right)$ than those cultivated in June $\left(5.54 \mathrm{t} \mathrm{ha}^{-1}\right)$ in 2018 . The former exceeded the latter by $2.28 \mathrm{t} \mathrm{ha}^{-1}$ in 2019. These differences between these two planting dates might have been due to varying environmental factors especially temperature and rainfall during seed development and maturation. The present study showed that when the temperature and rainfall increased towards the maturity of the plant, the biological and seed yield decreased. Rahman et al. (2005) reported that soybean yield decreased due to changes in sowing dates which related to the environmental conditions mostly observed during the plant life cycle.

Soil amendments also significantly $(p<0.05)$ affected pod yield of soybean in the two cropping seasons, with highest values in urea fertilizer and poultry droppings amended plots in 2018 and 2019, respectively. The lowest pod yield in both years occurred in the unamended control plots. Notably, the highest-yielding plots amended with N-rich urea were similar only to poultry droppings amended plots in 2018, but higher than only rice-husk dust amended and control plots in 2019. This observation is ascribed to the $\mathrm{N}$ fixed by soybean in the first year which obliterated the effects of $\mathrm{N}$ from soil amendments in the second year (Uzoh et al., 2017). Planting date $\times$ fertilizer type interaction showed higher $(p<0.05)$ pod yield due to planting in May and amending with NPK and poultry droppings in 2018 and 2019 cropping seasons, respectively.

As shown in Table 6 , soybean grain yield varied significantly $(p<0.05)$ in the two years of study due to differences in planting dates. These variations followed the trend of pod yield. This shows that the planted during the early part of the year and which took longer period to complete its life cycle had higher grain weight, while the one planted in June experienced higher temperature during the early phases and completed its life cycle rapidly, hence, lower grain weight. The result is in agreement with Yajam and Madani (2013) who observed that grain weight was affected by planting dates. The grain yield is the function of combined effects of all the yield components under the influence of a particular set of environmental conditions. The grain yield decreased little by little with delay in planting date.

Soil amendments significantly improved the soybean grain yield with poultry-droppings manure having the highest vales (3.83 and $\left.4.23 \mathrm{t} \mathrm{ha}^{-1}\right)$ in 2018 and 2019 cropping seasons, respectively over other amendments in the study.

\section{CONCLUSION}

Planting date is an important factor in soybean production in the derived savannah. Generally, planting soybean earlier in May could be an option for enhancing soil content of total nitrogen and soybean pod yield. However, delaying the planting till June could enhance such indices of soil quality as soil organic carbon content, mean-weight diameter of soil aggregates and soil organic carbon stock, while also enhancing soybean grain yield. Though compatible and effective with either planting dates, poultry droppings may not always be the soil amendment of choice, depending on the soil quality and/or soybean agronomic yield parameters whose improvements are desired at crop maturity. Thus, in adapting soybean from the core savanna for cultivation in the derived savanna zones, the time of the cropping season when it is planted has both agronomic and environmental implications, but the appropriate fertilizer must be used to grow the crop for clearer manifestations of such implications.

Table 6: Effects of planting date and fertilizer type on soybean pod weight and grain yield $\left(\mathrm{t} \mathrm{ha}^{-1}\right)$

\begin{tabular}{|c|c|c|c|c|c|c|}
\hline \multirow{2}{*}{ Amendments } & \multicolumn{3}{|c|}{2018} & \multicolumn{3}{|c|}{2019} \\
\hline & May & June & Mean & May & June & Mean \\
\hline & \multicolumn{6}{|c|}{ Pod yield $\left(\mathrm{t} \mathrm{ha}^{-1}\right)$} \\
\hline Control & 6.07 & 5.69 & 5.88 & 6.23 & 6.07 & 6.15 \\
\hline NPK-15:15:15 & 8.09 & 4.70 & 6.40 & 8.76 & 4.96 & 6.86 \\
\hline Poultry-droppings manure & 7.24 & 5.83 & 6.54 & 8.77 & 6.00 & 7.39 \\
\hline Rice-husk dust & 6.93 & 5.17 & 6.05 & 7.84 & 5.27 & 6.56 \\
\hline Swine-droppings manure & 7.01 & 5.82 & 6.41 & 7.79 & 5.86 & 6.82 \\
\hline Urea N-fertilizer & 7.91 & 6.02 & 6.97 & 8.39 & 5.93 & 7.16 \\
\hline Mean & 7.21 & 5.54 & 6.37 & 7.96 & 5.68 & 6.82 \\
\hline $\mathrm{LSD}_{0.05}$ for planting dates & & 1.32 & & & 1.11 & \\
\hline $\mathrm{LSD}_{0.05}$ for amendments & & 0.56 & & & 0.52 & \\
\hline \multirow[t]{2}{*}{$\mathrm{LSD}_{0.05}$ for planting dates $\times$} & & 1.05 & & & 0.91 & \\
\hline & \multicolumn{6}{|c|}{ Grain yield $\left(\mathrm{t} \mathrm{ha}^{-1}\right)$} \\
\hline Control & 4.19 & 2.04 & 3.11 & 4.19 & 2.67 & 3.43 \\
\hline NPK-15:15:15 & 4.94 & 2.43 & 3.68 & 5.07 & 3.02 & 4.05 \\
\hline Poultry-droppings manure & 4.60 & 3.05 & 3.83 & 5.08 & 3.38 & 4.23 \\
\hline Rice-husk dust & 3.58 & 2.45 & 3.01 & 4.08 & 3.11 & 3.60 \\
\hline Swine-droppings manure & 4.56 & 2.87 & 3.71 & 4.89 & 3.18 & 4.04 \\
\hline Urea N-fertilizer & 5.02 & 2.56 & 3.79 & 5.04 & 2.85 & 3.95 \\
\hline Mean & 4.48 & 2.57 & 3.52 & 4.72 & 3.04 & 3.88 \\
\hline $\mathrm{LSD}_{0.05}$ for planting dates & & 0.23 & & & 0.43 & \\
\hline $\mathrm{LSD}_{0.05}$ for amendments & & 0.30 & & & 0.52 & \\
\hline $\mathrm{LSD}_{0.05}$ for planting dates $\times$ & & 0.40 & & & NS & \\
\hline
\end{tabular}

LSD, least significant difference; NS, non-significant 


\section{REFERENCES}

Adesodun J.K. and Odejimi O.E. (2010). Carbon nitrogen sequestration potentials and structural stability of tropical Alfisol as influenced by pigcomposted manure. Int. Agrophys., 24, 333-338

Adubasim C.V., Igwenagu C.M., Josiah G.O., et al. (2018). Substitution of manure source and aerator in nursery media on sandy-loam topsoil and their fertility indices 4 months after formulation. Int. $J$. Recycl. Org. Waste Agric., 7 (4), 305-312. DOI: 10.1007/s40093-018-0216-8

Alghamdi S.S. (2004). Yield stability of some soybean genotypes across diverse environments. Pakistan $J$. Biol. Sci., 7 (12), 2109-2114

Asiegbu J.E and Okpara D.A. (2002). Soybean production in marginal soils of Southeastern Nigeria. $36^{\text {th }}$ Ann. Conf. Agric. Soc. Nig., Federal University of Technology, Owerri, Nigeria

Balashor E., Kren J. and Prochazkora B. (2010). Influence of plant residue management on microbial properties and water stable aggregates of two agricultural soils. Int. Agrophys., 24, 9-13

Bhattacharyya R., Chandra S., Singh R.D., Kundu S., Srivastra A.K. and Gupta H.S. (2007). Long-term farmyard manure application effects on properties of a silty clay loam soil under irrigated wheat-soybean rotation. Soil Tillage Res., 94, 386-396

Blake G.R. and Hartge K.H. (1986). Bulk density. In: Klute A. (ed.), Methods of Soil Analysis, Part 1 (pp. 363-382). Am. Soc. Agron., Madison WI

Bremner J.M. and Mulvaney C.S. (1982). Total nitrogen. In: Page A.L. et al. (eds.), Methods of Soil Analysis, No. 9: Part 2 (595-624). Am. Soc. Agron., Madison WI

Bronick C.J. and Lal R. (2005). Manuring and rotation effects on seed organic carbon concentration for different aggregate size fraction on two soils in Northeastern Ohio, USA. Soil Tillage Res., 81, 239-252

Calegari A. (2006). Plantas de cobertura. cap. 5. In: Plantio direto com qualidade. Lorinda: IAPAR; Foz do iguacu: ITAIPU Binacional

Calvino P.A., Sadras V.O. and Andrade F.H. (2003). Development, growth and yield of late-sown soybean in the Southern Pampas. Europ. J. Agro., 19, 265-275

Eshel G., Fine P. and Singer M. (2007). Total soil carbon and water quality: An implication for carbon sequestration. Soil Sci. Soc. Amer. J., 71, 397-405

Fatubarin A. and Olojugba M.R. (2014). Effect of rainfall season on the chemical properties of the soil of Southern Guinea Savanna ecosystem in Nigeria. $J$. Ecol. Nat. Environ., 6 (4), 182-189

Fekadu G., Hussein M. and Getinet A. (2009). Genotype $\times$ enivronment interactions and stability of soybean for grain yield and nutrition quality. Afr. Crop Sci. J., 17 (2), 87-99

Jarecki M.K. and Lal R. (2003). Crop management for soil carbon sequestration. Crit. Rev. Plant Sci., 22, 471-502

Kantolic A.G. and Slafer G.A. (2001). Photo period sensitivity after flowering and seed number determination in indeterminate soybean cultivars. Field Crop Res., 72, 109-118

Kemper D.W. and Rosenau R.C. (1986). Aggregate stability and size distribution. In: Klute A. (ed.), Methods of Soil Analysis, Part 1 (pp. 425-442). Am. Soc. Agron., Madison WI
Lal R. (2003). Cropping systems and soil carbon sequestration. Crit. Rev. Plant Sci., 22, 1-32

Lekwa G., Nnodi A.O., Okafor A.C., Chuta E.J., Ahumibe C.U. and Lekwa M.U. (1995). Detailed Soil Survey and Land Capability Evaluation of Federal College of Agriculture Site, Ishiagu - Final Report. Owerri: Pedro-Agro Technical Services (Nigeria) Limited, pp.12-21

Liu Y., Wang C., Peng Z. and Qie G. (2010). Soil enzyme activity and its relationship with soil physico-chemical properties in green areas of Chongwen District of Beijing. J. Northeast For. Univ., 38 (4), 66-70

Mbah C.N., Njoku C., Okolo C.C., Attoe E. and Osakwe U.C. (2017). Amelioration of a degraded Ultisol with hardwood biochar: Effects on soil physico-chemical properties and yield of cucumber (Cucumis sativus $\mathrm{L}$ ). Afr. J. Agric. Res., 12 (21), 1781-1792. https://doi. org/10.5897/AJAR2 016.11654

Mclean E.O. (1982). Soil $\mathrm{pH}$ and lime requirement. In: Page A.L. (ed.), Methods of Soil Analysis, Part 2: Chemical and Microbiological Properties ( ${ }^{\text {nd }}$ Ed.). Madison WI: American Society of Agronomy

Naeve S.L., Potter B.D., Quiring S.R., O'Neil T.A. and Kurle J.E. (2004). Influence of soybean plant population and row spacing on development and yield across planting dates in Minnesota. Univ. of Minnesota, Minneapolis. Retrieved Dec. 2007 from: www.soybeans.umn. edupdfs/2004asaposter1 spacingplanting_screen.pdf

Nelson D.W. and Sommers I.E. (1982). Total carbon, organic carbon and organic matter. In: Black C.A. (ed.), Methods of Soil Analysis, Part 3: Chemical Methods (pp. 961-1010). Soil Sci. Soc. Am. \& Am. Soc. Agron., Madison WI

Nnadi A.L., Nnanna P.I., Onyia V.N., Obalum S.E. and Igwe C.A. (2020). Growth and yield responses of high-density coverage sweet potato to liming and fertilizer combinations for sandy-loam Ultisols at Nsukka, southeastern Nigeria. In: Climate-Smart Soil Management, Soil Health/Quality and Land Management: Synergies for Sustainable Ecosystem Services (pp. 263-269), Proc. 44th Annual Conf. Soil Sci. Soc. Nig. (SSSN), 16-20 Mar. 2020 [Colloquia SSSN 44], Enugu State Univ. of Sci. \& Tech., Enugu, Nigeria

Nnadi A.L., Ugwu V.U., Nwite J.C., Obalum S.E., Igwe C.A. and Wakatsuki T. (2021). Manurial amendments and source of water for supplemental irrigation of sawah-rice system influenced soil quality and rice yield. Agro-Science, 20 (1), 95-102. https://dx.doi.org/10.4314/as.v20i1.15

Nottidge D.O., Ojeniyi S.O. and Asawalam D.O. (2005). Comparative effect of plant residue and NPK fertilizer on nutrient status and yield of maize in a humid Ultisol. Nig. J. Soil Sci., 15, 1-8

Nwite J.C. Igwe C.A. and Wakatsuki T. (2008). Evaluation of sawah rice management system in an inland valley in Southeastern Nigeria. I: Soil chemical properties and rice yield. Paddy Water Environ., 6 (3), 299-307. DOI: 10. 1007/s10333-0080123-0 299-307

Nwite J.C., Eneruvie B.E. and Nwafor S.O. (2016b). Impact of organo minerals and their integrated forms on soil fertility and maize productivity in Southeastern Nigeria. J. Agric. Ecol. Res. Int., 5 (3), 1-8. https://doi.org/10.9734/JAERI/2016/15192 
Nwite J.C., Essien B.A., Anaele M.U., Igwe C.A., Obalum S.E. and Okolo C. (2012c). Effect of rice husk and rice husk ash supplemented with poultry dropping on soil chemical properties, growth and yield of maize (Zea mays) in Ishiagu. Presented under Climate Change, Soil Management Alternatives and Sustainable Food Production, the 36th Annual Conf. Soil Sci. Soc. Nigeria (SSSN), 12-16 Mar. 2012, Hall of Fame, University of Nigeria, Nsukka, Nigeria

Nwite J.C., Igwe C.A. and Obalum S.E. (2011). The contributions of different ash sources to the improvement in properties of a degraded Ultisol and maize production in southeastern Nigeria. AmericanEurasian J. Sustainable Agric., 5 (1), 34-41

Nwite J.C., Keke C.I., Obalum S.E., Essien J.B., Anaele M.U. and Igwe C.A. (2013). Organo-mineral amendment options for enhancing soil fertility and nutrient composition and yield of fluted pumpkin. Int. J. Vegetable Sci, 19 (2), 188-199. https://doi.org/ 10.1080/19315260.2012.705233

Nwite J.C., Keke C.I., Obalum S.E., et al. (2012a). Evaluation of organo-minerals and inorganic fertilizer soles and their mixtures on some selected soil chemical properties and leaf nutrient composition of fluted pumpkin (Telfairia occidentalis Hook F.) in an Ultisol of southeastern Nigeria. Proc. Int. Agric. Conf., pp. 494-503, 6-9 May 2012, Anambra State University, Igbariam Campus, Anambra State, Nigeria

Nwite J.C., Obalum S.E., Igwe C.A. and Wakatsuki T. (2016a). Soil physical properties and grain yields of lowland rice in response to sawah preparation intensities and soil amendment types. Biol. Agric. Hort., 32 (3), 192-205. https://doi.org/10.1080/ 01448765.2016.1152507

Nwite J.C., Ogbodo E.N., Obalum S.E., Igbo V.C. and Igwe C.A. (2012b). Short-term response of soil physical properties of an Ultisol, and nutrient composition of fluted pumpkin to organic and inorganic fertilizer mixtures. J. Biol. Agric. Healthcare, 2 (10), 195-204

Nwite J.C., Unagwu B.O., Okolo C.C., Igwe C.A. and Wakatsuki T. (2019). Improving soil silicon and selected fertility status for rice production through rice-mill waste application in lowland sawah rice field of southeastern Nigeria. Int. J. Recycl. Org. Waste Agric., 8, 271-279 https://doi.org/10.1007/ s40093-019-00299-3

Obalum S.E. and Obi M.E. (2014). Measured versus estimated total porosity along structure-stability gradients of coarse-textured tropical soils with lowactivity clay. Environ. Earth Sci., 72 (6), 1953-1963. DOI: $10.1007 / \mathrm{s} 12665-014-3102-3$

Obalum S.E., Chibuike G.U., Peth S. and Ouyang Y. (2017). Soil organic matter as sole indicator of soil degradation. Environ. Monit. Assessment, 189 (4), Article 176. DOI: 10.1007/s10661-017-5881-y

Obalum S.E., Igwe C.A. and Obi M.E. (2012b). Soil moisture dynamics under rainfed sorghum and soybean on contrasting tillage-mulch seedbeds in a mineral sandy loam at derived savanna of south-eastern Nigeria. Archives Agron. Soil Sci., 58 (11), 1205-1227. https://doi.org/10.1080/03650340.2011.575065

Obalum S.E., Igwe C.A., Obi M.E. and Wakatsuki T. (2011a). Water use and grain yield response of rainfed soybean to tillage-mulch practices in southeastern Nigeria. Scientia Agricola, 68 (5), 554-561. https://doi.org/10.1590/S0103-90162011000500007
Obalum S.E., Ogumba P.O. and Uzoh I.M. (2020). Influence of tillage-seedbed and manure-NPKmicronutrient management options on selected soil properties of sandy-loam Ultisols evaluated using sweet potato. Nig. J. Soil Sci., 30 (3), 117-125

Obalum S.E., Okpara I.M., Obi M.E. and Wakatsuki T. (2011b). Short-term effects of tillage-mulch practices under sorghum and soybean on organic carbon and eutrophic status of a degraded Ultisol in southeastern Nigeria. Trop. Subtrop. Agroecosys., 14 (2), 393-403

Obalum S.E., Watanabe Y., Igwe C.A., Obi M.E. and Wakatsuki T. (2012). Carbon stock in the solum of some coarse-textured soils under secondary forest, grassland fallow and bare footpath in the derived savanna of southeastern Nigeria. Soil Res., 50 (2), 157-166. https://doi.org/10.1071/SR11096

Ogoke I.J., Togun A.O., Carsky R.J. and Dashiell K.E. (2006). N2 fixation by soybean in the Nigerian moist savanna: effects of maturity class and phosphorus fertilizer. Tropicultura, 24 (4), 193-199

Ohu J.O., Mamman E. and Mustaph A.A. (2009). Impact of organic material incorporation with soil in relation to their shear strength and water properties. Int. Agrophys., 23, 155-162

Okpara D.A. and Ibiam B. (2000). Evaluation of soybean varieties for adaptability to a bound tropical environin southeastern Nigeria. J. Sustainable Agric. Environ., 2, 26-31

Rahman M.M., Hapton J.G. and Hill M.J. (2005). The effect of time of sowing of soybean seed quality. Seed Sci. Technol., 33, 687-697

Umeugokwe C.P., Ugwu V.U., Umeugochukwu O.P., et al. (2021). Soil fertility indices of tropical loamy sand as influenced by bambara groundnut variety, plant spacing and fertilizer type. Agro-Science, 20 (1), 65-71. https://dx.doi.org/10.4314/as.v20i1.11

Unagwu B.O., Asadu C.L.A. and Obalum S.E. (2013). Maize performance in a sandy loam Ultisol amended with NPK 15-15-15 and poultry manure. In: The Role of Crop Science in the Agricultural Transformation Agenda, Proc. 1st National Annual Conf. Crop Sci. Soc. Nigeria (CSSN), pp. 135-141, 15-19 Sep. 2013, University of Nigeria, Nsukka, Nigeria

Uzoh I.M., Obalum S.E., Igwe C.A. and Abaidoo R.C. (2017). Quantitative separation of nitrogen and nonnitrogen rotation benefits for maize following velvet bean under selected soil management practices. Agric. Res., 6 (4), 378-388. https://doi.org/10.1007/ s40003-017-0272-8

Wan S., Dafeng H. and Luo Y. (2001). Fire effects on nitrogen pools and dynamics in terrestrial ecosystems: A meta-analysis. Ecol. Appl., 11, 1349-1365. DOI: 10.1890/1051-0761(2001)011[1349:FEONPA]2.0.CO;2

Wang C.J., Pan G.X., Tian Y.G., Li L.Q., Zhang X.H. and Han X.J. (2010). Changes in cropland topsoil organic carbon with different fertilizations under long-term agro-ecosystem experiments across mainland China. Sci. China Life Sci., 53 (7), 858-867

Yajam S. and Madani H. (2013). Delay sowing date and its effect on Iranian winter wheat cultivars yield and yield components. Ann. Biol. Res., 4 (6), 270-275

Yusuf I.A. and Idowu A.A. (2001). Evaluation of four soybean varieties for performance under different lime regimes on the acid soil of Uyo. Trop. Oil Seed J., 6, 65-70

Zhang Q.Y., Gao Q.L., Herbert S.J., Li Y.S. and Hashemi A.M. (2010). Influence of sowing date on photological stages, seed growth and marketable yield of farm vegetable soybean cultivars in Northeastern USA. Afr. J. Agric. Res., 5, 2556-25620 